\title{
Upland rice sowing in conservationist production systems in Vale do Ribeira
}

\section{Semeadura de arroz de sequeiro em sistemas conservacionistas de produção no Vale do Ribeira}

\section{Wilson José Oliveira de SOUZA; Eduardo Nardini GOMES ${ }^{2}$; Artur José de SANTANA NETO ${ }^{3}$; César Henrique de JESUS ${ }^{4}$; Samuel FERRARI ${ }^{5}$; Tamires TANGERINO ${ }^{6}$}

\begin{abstract}
${ }^{1}$ Autor para correspondência; Engenheiro Agrônomo, Prof. Assistente Doutor, UNESP/Campus Experimental de Registro, LAMMEC - Laboratório de Máquinas e Mecanização Agrícola. Tutor do PET - Engenharia Agronômica (PET Agro Registro) Rua Nelson Brihi Badur, n. 430, Vila Tupi. CEP. 11.900-000 - Registro, SP. Fone: 1338282928 , souza@registro.unesp.br

${ }_{2}$ Prof. Assistente Doutor, UNESP/Campus Experimental de Registro. engomes@registro.unesp.br

${ }^{3}$ Aluno de graduação em Agronomia, UNESP/Campus Experimental de Registro. arturjsn.agronomo@yahoo.com.br

${ }^{4}$ Aluno de graduação em Agronomia, UNESP/Campus Experimental de Registro. cesar_agro7@hotmail.com

${ }^{5}$ Prof. Assistente Doutor, UNESP/Campus Experimental de Registro. ferrari@registro.unesp.br

${ }^{6}$ Engenheira Agrônoma pela UNESP/Campus Experimental de Registro. tamiresmall@hotmail.com
\end{abstract}

Recebido em: 21-03-2015; Aceito em: 27-08-2015

\begin{abstract}
Vale do Ribeira (Ribeira Valley), region located in the southern of São Paulo State, Brazil, has little more than $30 \%$ of agriculturable area, the conservationist systems being promising to optimize the use of the soil and of the agricultural machines. The objective was to evaluate the effective field capacity of a multiple seeder-fertilizer, as well as plant and soil parameters associated with the effects of the machine. The experiment was carried out in the Experimental Campus of UNESP, in the Registro County, in the agricultural year 2011/2012, under Cfa humid subtropical climate with hot summer, according to the Köppen classification, with average temperature of $22{ }^{\circ} \mathrm{C}$ and annual rainfall of $1400 \mathrm{~mm}$. The experimental area has alluvial soils of the type eutrophic Cambisol. The treatments used were CT (conventional tillage), MT (minimum tillage) and NT (no-tillage). The data collected showed that (1) the highest surface coverage in NT reduced soil temperature at $14 \mathrm{~h}$, as well as the thermal amplitude; (2) the average number of days to seedling emergence was higher in no-tillage, caused by the greater surface coverage and the lower soil temperature in the hottest period of the day; (3) the initial stand of the rice crop was similar in the three tillage systems.
\end{abstract}

Additional keywords: minimum tillage; no-tillage; seeder; soil temperature.

\section{Resumo}

O Vale do Ribeira, região localizada ao sul do Estado de São Paulo, possui pouco mais que $30 \%$ de área agriculturável, sendo os sistemas conservacionistas promissores na otimização do uso do solo e de máquinas agrícolas. $\mathrm{O}$ objetivo foi avaliar a capacidade de campo efetiva de uma semeadora-adubadora múltipla, bem como parâmetros de planta e solo associados aos efeitos da máquina. O experimento foi conduzido no Campus Experimental da UNESP, município de Registro, no ano agrícola 2011/2012, sob clima Cfa subtropical úmido com verão quente, conforme a classificação de Köppen, com temperatura média de $22{ }^{\circ} \mathrm{C}$ e precipitação anual de $1400 \mathrm{~mm}$. A área experimental possui solos aluviais do tipo Cambissolos eutróficos. Os tratamentos utilizados foram PC (preparo convencional), CM (cultivo mínimo) e PD (semeadura direta). Os dados coletados mostraram que (1) a maior cobertura da superfície no PD reduziu a temperatura do solo às $14 \mathrm{~h}$, bem como a amplitude térmica; (2) o número médio de dias para emergência das plântulas foi maior na semeadura direta, originado pela maior cobertura da superfície e menor temperatura do solo no período mais quente do dia; (3) o estande inicial da cultura do arroz foi semelhante nos três sistemas de preparo do solo.

Palavras-chave adicionais: cultivo mínimo; plantio direto; semeadora; temperatura do solo.

\section{Introduction}

The agricultural crop production is widely affected by the management of the adopted soil. According to Mello et al. (2003), soil preparation improves the surface conditions favoring the uniformity of germination of seeds, the growth and development of plants by the water and air movement, the control of competing plants and incorporation of lime and fertilizer, as well as increased storage capacity of water in the soil and irrigation water saving. Thus, the use of different soil management systems has as basic premise the maintainance of the physical quality of the soil in 
order to maximize the production of the cultivation area (Akune, 2015). Nonetheless, according to the edaphoclimatic conditions of the region of cultivation, intensive tillage can promote deterioration in the physical, chemical and biological attributes of the soil, directly affecting crop productivity.

Hence, to mitigate the degrading impact of conventional soil management on the agroecosystem, the ASAE (2005) recommends the implementation of conservationist tillage practices that are based on the use of vegetation cover considered responsible for soil protection. The no-tillage system adoption is aimed at expressing the genetic potential of crops grown by maximizing the environmental factor and the soil factor, not degrading them. However, favoring the rationalization, which consider aspects related to soil (size and shape of the area, texture, declivity, vegetation cover, fertility, compaction and regularity of the surface leveling), culture (initial stand and crop establishment), machinery (working speed, operational capability and performance) and their interrelationships (Embrapa, 2011). According to Cortez et al. (2007), the modernization and development of new specific machines for the no-tillage system (NTS) allowed its use with more efficiency, by sowing directly below a layer of straw with minimum tillage and with seed and fertilizer distribution in the recommended depth. Moreover, Silva et al. (2008) point out that the depth of seed deposition, related to the edaphoclimatic conditions, seed characteristics and crop management, can influence germination.

In this way, the work aimed to study the rice sowing operation evaluating the operational capability of the seeder-fertilizer, the average number of days to seedling emergence, as well as the coverage and temperature variation of the soil in systems of conventional tillage, minimum tillage and no-tillage.

\section{Material and methods}

The experiment was conducted in the experimental area of UNESP, Experimental Campus of Registro, São Paulo, located in the geographical coordinates $24^{\circ} 31^{\prime} 58^{\prime \prime}$ S latitude and $47^{\circ} 51^{\prime} 35^{\prime \prime}$ W longitude, with an average altitude of $25 \mathrm{~m}$. The climate is humid subtropical Cfa with hot summer, according to the Köppen classification, with an average temperature of $22{ }^{\circ} \mathrm{C}$ and average annual rainfall of $1400 \mathrm{~mm}$. The soil of the experimental area is part of the Environmental Systems Units, defined by Ross (2002) as System of the plains and river terraces of Ribeira do lguape, described as flat lands in the Low Ribeira and, or, Ribeira Tectonic Depression region, of modern sediments, in alluvial soils of the type eutrophic Cambisols in amount areas and of the type eutrophic Hydromorphic in lowland soils.

Before the experiment, it were collected single soil samples in May 2011, in 20 points at random, in the depths of 0-0.20 m and 0.20-0.40 m. Simple samples from each depth were transferred to a clean container and homogenized, being subsequently removed a composite sample, which was sent to the laboratory for chemical analysis of routine and of micronutrients, whose results are shown in Table 1.

Table 1 - Results of routine chemical analyses for fertility in the experimental area, prior to the experiment, in March 2011.

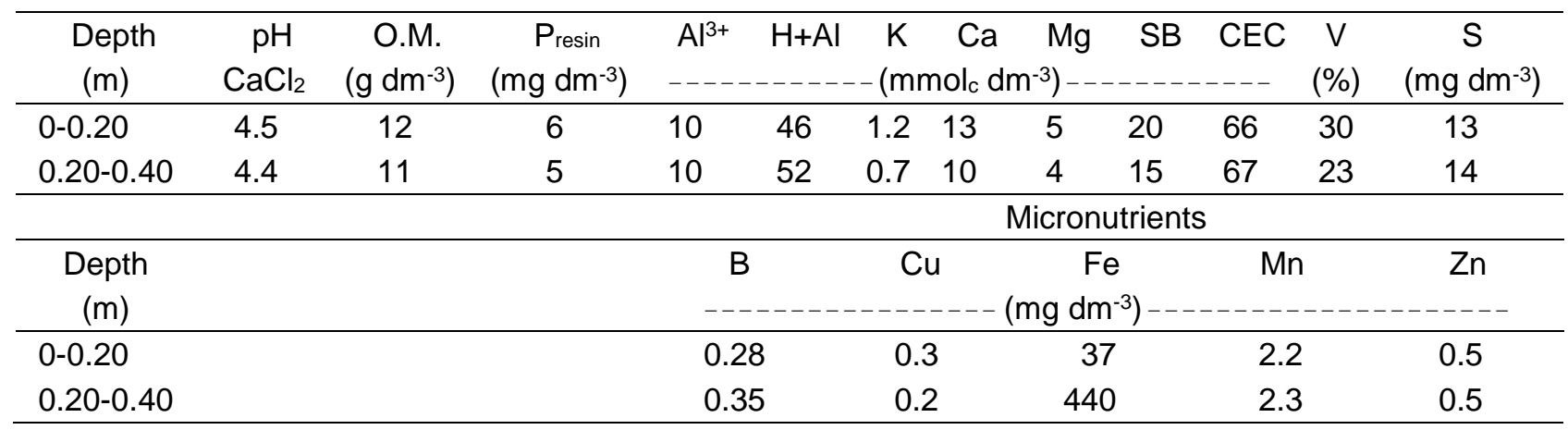

The analyses were performed at the Soil Laboratory of the Department of Soils and Fertilizers, FCAV/UNESP, Jaboticabal Campus, SP.

The experiment was carried out on tracks, using experimental design in randomized blocks, with three tillage systems: CT - conventional tillage with disk harrow, followed by two light diskings; MT minimum tillage with use of chisel plow equipped with fluted roller; NT - no-tillage system, with pre-planting desiccation and without soil preparation. The treatments had 12 repetitions, constituting of 36 plots with unit dimensions of $6.0 \times 20 \mathrm{~m}$, totaling $120 \mathrm{~m}^{2}$.

The area selected for experimental implementation was occupied with degraded pasture, without grazing for two years. The implementation of the experiment began with the desiccation of the total area on 11-13-2011, using 8.0 L ha-1 of glyphosate, in 
$200 \mathrm{~L} \mathrm{ha}^{-1}$ syrup. The first plowing in CT treatment was performed with 12-disk harrow, on 12-21-2011, at the average depth of $0.15 \mathrm{~m}$. The rapid reinfestation of weeds in the area demanded new desiccation, held on 01-10-2012, only on parcels intended to treatments with minimum tillage (MT) and no-tillage (NT). On the same day it was held the soil acidity correction with the broadcast application of 2.0 $\mathrm{t}^{\mathrm{a}} \mathrm{a}^{-1}$ of calcitic limestone (PRNT $75.5 \%$ ), in total area (Raij et al., 1997), soon after desiccation. Then it was carried out, in the CT treatment, the second plowing with disk harrow, and in plots with MT, subsoiling operation in the average depth of $0.40 \mathrm{~m}$, with subsoiler with five rods equipped with non-winged ferrules. On 01-11-2012, in the CT treatment was performed another harrowing operation at the average depth of $0.10 \mathrm{~m}$, with 32 disk-harrow.

Sowing was carried out using a multiple seeder-fertilizer of 9 lines in continuous flow, equipped with military-type tires with $52 \mathrm{lbf} \mathrm{pol}^{-2}$ pressure, flat disks for cutting straw and furrow opener with offset double disk (for fertilizer and seeds), with depth control wheels and closing of hard rubber groove. Reservoirs of seeds and fertilizers have been filled up to half of their capacities in order to ensure proper distribution of inputs. Sowing operation was performed, on 01-13-2012, using $130 \mathrm{~kg} \mathrm{ha}^{-1}$ certified seeds of rice (Oryza sativa L.), cultivar IAC 22, deposited in rows spaced $0.35 \mathrm{~m}$ and at the depth of $0.02 \mathrm{~m}$. In the planting fertilizer were applied $350 \mathrm{~kg} \mathrm{ha}^{-1}$ of the commercial formula NPK 04-14-08 in the planting furrow, as recommended by Raij et al. (1997). The theoretical speed $\left(5.5 \mathrm{~km} \mathrm{~h}^{-1}\right.$, $1.53 \mathrm{~m} \mathrm{~s}^{-1}$ ) of the operation was established as a function of the speed scaling $\left(1 \mathrm{st} \mathrm{H}_{\mathrm{T}}\right)$ of the tractor with $96.33 \mathrm{~kW}$ (130 hp) engine power, working at 1500 RPM, with assisted front wheel drive (FWD) triggered.

The real speed of work of the sower was determined by collecting the time spent by the set tractor + seeder-fertilizer + operator to travel the length of the plot (route), using Equation (1).

$$
\mathrm{S}=\frac{\mathrm{d}}{\mathrm{t}}
$$

Wherein: $S$ is real speed of displacement $\left(\mathrm{m} \mathrm{s}^{-1}\right)$ on the course; $d$ is distance (length of the plot), in meters; $t$ - time spent by the motomechanized set on the course (s).

The Effective Field Capacity (EFC) was determined by measuring the effective width of work of the seeder in the plot and the real working speed (Equation 1), adopting the $75 \%$ field efficiency (ASAE, 1999), using Equation 2. The effective working width was measured at two points of each plot after the passage of the seeder, thus, the considered reading of each plot refers to the average of two measurements.
$\mathrm{EFC}=\mathrm{W} \mathrm{SF}_{\text {ef }} 0.36$

Wherein: EFC is Effective Field Capacity (ha $\left.\mathrm{h}^{-1}\right)$; W is effective working width of the seeder-fertilizer $(\mathrm{m})$; $S$ is real speed of displacement $\left(\mathrm{m} \mathrm{s}^{-1}\right) ; F_{\text {ef }}$ - field efficiency to the seeder-fertilizer and 0.36 is the unit conversion factor (from $\mathrm{m}^{2} \mathrm{~s}^{-1}$ to ha $\mathrm{h}^{-1}$ ).

The average number of days to seedling emergence $(\mathrm{M})$ was determined according to the methodology described by Maguire (1962). In each plot, $2 \mathrm{~m}$ were marked in three central rows, on which were performed daily counts from the beginning of seedling emergence until the stabilization of the count, with values calculated using Equation 3.

$$
M=\left\{\left(N_{1} G_{1}\right)+\left(N_{2} G_{2}\right)+. .+\left(N_{n} G_{n}\right)\right\}\left(G_{1}+G_{2}++\ldots+G_{n}\right)^{-1}
$$

Wherein: $M$ is the average number of days to seedling emergence; $N_{1}$ is the number of days elapsed between the sowing and the first count; $G_{1}$ is the number of emerged seedlings on the first count; $\mathrm{N}_{2}$ is the number of days elapsed between the sowing and the second count; $\mathrm{G}_{2}$ is the number of emerged seedlings between the first and second counts; $N_{n}$ is the number of days between the sowing and the last count; $G_{n}$ is the number of emerged seedlings between the penultimate and the last count.

The initial stand (IS) was determined 17 days after seedling emergence, on 02-07-2012, in the three central lines with length of 2 meters, within each plot. The quantification was carried out after checking the stability of the seedling emergence, calculating the number of plants per square meter, according to Equation 4.

$\mathrm{IS}=\frac{\mathrm{N}_{\mathrm{pl}}}{\mathrm{d}_{1} \mathrm{~s}}$

Wherein: IS is the initial stand of culture (plants $\mathrm{m}^{-2}$ ); $\mathrm{Npl}$ is the number of plants counted in $d_{l}$; $d_{l}$ is the distance in which the count was conducted in the plot $(m)$; $s$ is the spacing between rows of the crop $(m)$.

The percentage of soil cover was quantified on 01-16-2012, three days after the rice sowing operation, at two points per plot (Laflen et al., 1981). In each plot, a $50 \mathrm{~m}$ rope with a knot every $0.5 \mathrm{~m}$ was extended on the surface, counting the number of nodes coincident with any straw fragment that covered the soil, representing the percentage of soil cover.

The soil temperature was measured at two points of each plot, using the electronic meter connected to a metal rod (copper-constantan), at the depth of $0-0.10 \mathrm{~m}$, in two hours, at $9 \mathrm{~h}$ and $14 \mathrm{~h}$, six days after sowing (01-19-2012). Soil moisture was determined on the same day at $14 \mathrm{~h}$ and soil depth using the gravimetric method as described by Embrapa (1997). 
Data referring to the parameters studied were tabulated and statistically analyzed applying analysis of variance by $F$ test. When the test showed significant differences between treatments, it was held the comparison of means by Tukey test at $5 \%$ probability, in order to identify existing statistical differences between treatments (Pimentel-Gomes \& Garcia, 2002).

\section{Results and discussions}

The parameters studied showed low coefficients of variation, indicating that the data collected are consistent. In the literature, several authors (Kaneko et al., 2010, Nascente et al., 2011, Fonseca et al., 2012) emphasize the importance of seeding operations - subsequently, of the sowing depth and soil conditions - for the seeds.

The results obtained show that the speed of displacement of the tractor-seeder-operator set was similar in the three tillage systems (Table 2), corroborating Bertolini et al. (2012), who found no significant influence of no-tillage and reduced tillage on seeding speed, analyzing the energy demand of the sower-fertilizer on corn planting in different soil managements, in the Botucatu County, SP. Furlani et al. (2005) also found no significant differences for seeding speed between conventional tillage (CT) and no-tillage (NT). However, the minimum tillage (MT) differed statistically from both treatments, in studies with seeder-fertilizer performance, as a result of the soil management system, in maize crop, in eutrophic Dark Red Latosol of loamy texture, in the Jaboticabal County, SP. Results reported by Silva et al. (1998), who evaluated the performance of seeder-fertilizers in upland rice planting in different soil tillage systems, in Dark Red Latosol, found a significant difference to the speed of sowing between conventional (CT) and reduced (RT) tillage, in the Santo Antônio de Goiás County, GO. Chioderoli et al. (2010) found significant influence of soil management (NT, MT and CT) on seeding speed, in the implementation of corn in eutroferric Red Latosol, in Jaboticabal, SP.

The seeding speed obtained on CT showed higher value $\left(1.48 \mathrm{~m} \mathrm{~s}^{-1}\right)$ than NT $\left(1.44 \mathrm{~m} \mathrm{~s}^{-1}\right)$ and MT (1.41 $\mathrm{m} \mathrm{s}^{-1}$ ) (Table 2), confirming the results obtained by Silva et al. (1998) and Bertolini et al. (2012), agreeing in part with Furlani et al. (2005), who found equal seeding speed for CT and NT, however superior to MT. Notwithstanding, these results differ from those obtained by Vale et al. (2008), who found real speed of the motomechanized set of $1.48 \mathrm{~m} \mathrm{~s}^{-1}$ for the CT in corn sowing and of $1.77 \mathrm{~m} \mathrm{~s}^{-1}$ for NT in sorghum planting, in Campos dos Goytacazes, RJ. Studies of Chioderoli et al. (2010) showed higher values of sowing speed under no-tillage compared to conventional and minimum tillage. These authors state that the lower speed in CT is connected to the operations of preparation before sowing that disaggregate the soil, reducing the tire grip capacity, which contributes to increasing slip rate. Nonetheless, the reverse occurs in the NTS, the absence of tillage contributes to increasing the tire grip, resulting in lower slip rate and consequently in greater speed. Considering the theoretical speed $\left(5.5 \mathrm{~km} \mathrm{~h}^{-1}\right)$, it was found that the real speed was on average $5.8 \%$ lower, due to the floor condition, the presence and amount of soil cover (Figure 1), soil moisture, among other factors. Reis et al. (2007) verified slippage index of the tractor rear wheels, in the order of $8 \%$, which contributed significantly to the reduction in the forward speed of the motomechanized set.

The effective field capacity (EFC) at sowing operation showed significant difference depending on the type of tillage (Table 2), this being higher on the CT in relation to NT, but similar to the MT. Reis et al. (2014) also found EFC values similar between the CT and the MT. Bertolini et al. (2012) found no statistical difference for EFC as a result of soil management systems, in dystroferric Red Nitosol. However, results opposite to those of this work were obtained by Furlani et al. (2005), who found greater effective field capacity at sowing operation in notillage and conventional tillage systems, in relation to the reduced tillage.

The type of soil management for the rice culture implantation influenced the seedling emergence speed (Table 2). In NT, the average number of days to seedling emergence (M) was statistically higher than in CT and similar to MT. These results contrast with those of Silva et al. (1998), which found a lower speed index of emergence of the rice plant in reduced tillage, compared with the conventional tillage. However, Oi (2008) found uniformity in the emergence of rice plants in three soil managements (CT, MT and NT), in dystroferric Red Latosol, in the Ilha Solteira County, SP. This difference in the seedling emergence speed did not affect significantly the establishment of the rice crop, since the initial stand of culture (IS) was similar in the three tillage systems (Table 2).

The Initial Stand of culture (IS) was not affected by soil management (Table 2), corroborating Arf et al. (2005), who assessed the development of the upland rice crop, in typical dystrophic Red Latosol (typical dystrophic Hapludox), clayey, in the region of Selvíria, MS. Similarly, Kraemer et al. (2009) found no significant influence of the type of tillage on the initial stand of rice cultivation in eutrophic Hydromorphic Planosol, arenic, in Santa Maria, RS. Notwithstanding, different results were obtained by de Silva et al. (1998), who found a lower initial stand of the rice crop in reduced tillage compared to conventional tillage. 
Table 2 - Analysis of variance and mean test for the variables Real working speed (S), Effective Field Capacity (EFC), Average number of days to seedling emergence (M) and Initial Stand of culture (IS) in three tillage systems, in the agricultural year 2011/2012, in Vale do Ribeira (Registro - SP).

\begin{tabular}{lcccc}
\hline Type of Tillage & $\begin{array}{c}\mathrm{S} \\
\left(\mathrm{m} \mathrm{s}^{-1}\right)\end{array}$ & $\begin{array}{c}\mathrm{EFC} \\
\left(\mathrm{ha} \mathrm{h}^{-1}\right)\end{array}$ & $\begin{array}{c}\mathrm{M} \\
(\text { days })\end{array}$ & $\begin{array}{c}\text { IS } \\
\left.\text { (plants } \mathrm{m}^{-2}\right)\end{array}$ \\
\hline CT & 1.48 & $2.52 \mathrm{~b}$ & $8.38 \mathrm{a}$ & 155.04 \\
MT & 1.41 & $2.43 \mathrm{ab}$ & $8.49 \mathrm{ab}$ & 151.39 \\
NT & 1.45 & $2.36 \mathrm{a}$ & $8.89 \mathrm{~b}$ & 131.31 \\
\hline Mean & 1.44 & 2.44 & 8.59 & 145.91 \\
F Test & 0.0876 NS & $0.0329^{*}$ & $0.0315^{*}$ & 0.0463 NS \\
CV $(\%)$ & 4.75 & 5.91 & 5.38 & 16.11 \\
\hline
\end{tabular}

$\mathrm{CT}=$ conventional tillage; $\mathrm{MT}=$ minimum tillage; $\mathrm{NT}=$ no-tillage; $\mathrm{CV}=$ coefficient of variation; Means followed by the same letter in the column do not differ at $5 \%$ probability; ${ }^{\mathrm{NS}}=$ non-significant; ${ }^{*}=$ significant at $5 \%$ probability.

In the study of the percentage of soil cover (COV) there was a significant difference between the three types of soil managements (Table 3 ), being observed considerable reduction in the percentage of vegetable waste with the intensification of the mobilization according to the soil preparation.

The percentage of vegetation cover influenced the soil temperature in the two measured times (Table 3). In the morning (9h), it was observed lower temperature in the soil of the CT, followed by MT (minimum tillage) and NT (no-tillage). Nonetheless, opposite result was observed in the afternoon (14h), with higher temperatures in CT and MT and lower in NT (Table 3). This soil temperature behavior as a function of time and management system is directly related to the amount of vegetation cover percentage in the soil surface, given the correlations observed and presented in Table 4. Thus, it is noteworthy that the NTS was the preparation system with the highest percentage of vegetation cover and lower thermal oscillation in the soil subsurface layer. Studies by Martorano et al. (2009), with indicators of soil water condition using soybean in no-tillage and conventional tillage systems, verified reduction of maximum temperatures and thermal amplitude of the soil in the no-tillage system compared to the conventional system, which interferes significantly in the germination process of seeds and early crop establishment.

Soil moisture, measured based on mass $(\mathrm{Gm})$, was higher in CT when compared to NT (Table 3), confirming Rodrigues et al. (2011), who found similar results in dystroferric Red Nitosol, in sorghum cultivation, in Botucatu, SP. According to Silva et al. (2005), in the surface layer, the soil moisture can be higher in CT in relation to the other tillage systems. This can possibly be explained by the effect of tillage, with trend of macropores increase. However, these results disagree with Kamimura et al. (2009), who found no influence of tillage on soil water content in dystrophic Red Latosol cultivated with rice, in Selvíria, MS. Cavalcante et al. (2011), in studies conducted on dystrophic Red Latosol, found higher water content in NT when compared to CT, in the llha Solteira County, SP. Moreover, Alam et al. (2014) found no significant variation in the water content according to the different managements of the soil for four consecutive years of crop assessment with wheat-bean-rice, in sandy loam texture soil, in Gazipur, Bangladesh.

Table 3 - Analysis of variance and mean test for the variables percentage of soil cover (COV), temperature (T soil) and Gravimetric moisture on a dry basis $(\mathrm{Gm})$ of the soil, in three tillage systems, in the agricultural year 2011/2012, in Vale do Ribeira (Registro - SP).

\begin{tabular}{|c|c|c|c|c|}
\hline \multirow{2}{*}{$\begin{array}{l}\text { Type of } \\
\text { tillage }\end{array}$} & \multirow{2}{*}{$\begin{array}{c}\operatorname{COV}^{(1)} \\
(\%)\end{array}$} & \multicolumn{2}{|c|}{ T soil $\left({ }^{\circ} \mathrm{C}\right)^{(2)}$} & \multirow{2}{*}{$\begin{array}{l}\mathrm{Gm}^{(2)} \\
\left(\mathrm{g} \mathrm{g}^{-1}\right)\end{array}$} \\
\hline & & $9 \mathrm{~h}$ & $14 \mathrm{~h}$ & \\
\hline CT & $7.92 \mathrm{a}$ & $25.30 \mathrm{a}$ & $31.33 \mathrm{~b}$ & $0.24 b$ \\
\hline MT & $42.96 \mathrm{~b}$ & $25.59 \mathrm{~b}$ & $31.46 \mathrm{~b}$ & $0.22 a b$ \\
\hline NT & $94.58 \mathrm{c}$ & $26.13 \mathrm{c}$ & $29.73 \mathrm{a}$ & $0.20 \mathrm{a}$ \\
\hline Mean & 48.49 & 25.67 & 30.84 & 0.22 \\
\hline F Test & $0.00001^{* *}$ & $0.00001^{* *}$ & $0.0003^{* *}$ & $0.0020^{\star *}$ \\
\hline CV (\%) & 14.22 & 0.31 & 1.70 & 5.77 \\
\hline
\end{tabular}

$\mathrm{CT}=$ conventional tillage; $\mathrm{MT}=$ minimum tillage; $\mathrm{NT}=$ no-tillage system $; \mathrm{T}=$ temperature of the soil; $\mathrm{Gm}=$ gravimetric moisture of the soil on 01-19-2012, at the depth of $0-0.10 \mathrm{~m} ; \mathrm{CV}=$ coefficient of variation; Means followed by the same letter in the column do not differ at $5 \%$ probability; ${ }^{N S}=$ non-significant; ${ }^{* *}=$ significant at $1 \%$ probability.

Correlation analysis (Table 4) suggests inverse behavior between soil cover and moisture, which does not always reflect the reality. In this test, it must be considered that such an effect on the gravimetric humidity should be associated with the characteristics of the soil in the region (texture from average to silty in the $0-0.20 \mathrm{~m}$ layer, with the presence of expansive clays) and especially with the type of 
preparation. The mechanical tillage tends to break down the soil during mobilization, in addition to promote consolidation below the mobilized layer by the passage of active organs, increasing the soil density and reducing the water infiltration capacity (Torres et al., 2011), already critical in the studied soil.

When the soil is not mobilized (NT), the tubules left by the decomposition of the roots of plants previously installed are preserved, facilitating the water infiltration, promoting greater displacement of water in the profile. For the peculiarity of the soils of the region, the water stays longer in the surface layer, which saturates faster and leads to greater losses of soil, as visually observed in the experimental plots. Martorano et al. (2009), studying the soil water condition indicators in typical Dystrophic Red Argisol, cultivated with soybeans, in the Eldorado do Sul County, RS, found that the soil drying time was higher under no-tillage compared to the conventional system, providing greater soil water availability in times of Indian summer.

Considering the analysis of correlation between IS and M (Table 4), it was found, for this experiment, independence between the two variables. According to Silva (2004), the use of lagged double disks without straw cutting disks tends to reduce the speed of emergence of rice seedlings, which may explain in part the observed behavior in the no-till system.

Another factor that can influence seedling emergence is the soil temperature, which is related to the vegetation cover. This influence was observed in the results of the experiment, where $M$ increased with the increase in the coverage of the soil surface (Table 5), explaining in part the largest number of days to seedling emergence (M) in NT. Higher soil temperatures on the CT in the hottest hours of the day (14h) tend to contribute to the reduction in the $M$ of the rice, given the negative (Table 4) and linear (Table 5) correlation observed in this experiment. Although the COV data present linear and significant negative correlation with the IS (Table 4), this was not observed in the treatments studied, since there was a difference in the soil cover percentage (Table 3 ), but not in IS (Table 2).

Table 4 - Correlation coefficients $(R)$ between the variables studied in the implementation of the rice crop in three tillage systems, in the agricultural year 2011/2012, in Vale do Ribeira (Registro - SP).

\begin{tabular}{|c|c|c|c|c|c|c|c|c|c|}
\hline \multirow{2}{*}{ Variables } & \multirow{2}{*}{ Units } & \multirow{2}{*}{$\begin{array}{c}\mathrm{S} \\
\left(\mathrm{m} \mathrm{s}^{-1}\right)\end{array}$} & \multirow{2}{*}{$\begin{array}{c}\text { EFC } \\
\left(\text { ha h }^{-1}\right)\end{array}$} & \multirow{2}{*}{$\begin{array}{c}\mathrm{M} \\
\text { (days) }\end{array}$} & \multirow{2}{*}{ 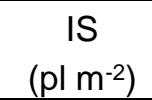 } & \multirow{2}{*}{$\begin{array}{c}\text { COV } \\
(\%)\end{array}$} & \multicolumn{2}{|c|}{$\mathrm{T}$ soil $\left({ }^{\circ} \mathrm{C}\right)$} & \multirow{2}{*}{$\begin{array}{c}\mathrm{Gm} \\
\left(\mathrm{g} \mathrm{g} \mathrm{g}^{-1}\right)\end{array}$} \\
\hline & & & & & & & $9 \mathrm{~h}$ & $14 \mathrm{~h}$ & \\
\hline $\mathrm{S}$ & $\left(\mathrm{m} \mathrm{s}^{-1}\right)$ & 1 & & & & & & & \\
\hline EFC & $\left(h^{\prime} h^{-1}\right)$ & 0.7503 & 1 & & & & & & \\
\hline M & ays)' & -0.0821 & -0.2140 & 1 & & & & & \\
\hline IS & $\left(\mathrm{pl} \mathrm{m}^{-2}\right)$ & -0.0984 & 0.1379 & -0.2839 & 1 & & & & \\
\hline COV & (\%) & -0.1383 & -0.4472 & 0.4383 & -0.3709 & 1 & & & \\
\hline \multirow{2}{*}{ T Soil $\left({ }^{\circ} \mathrm{C}\right)$} & $9 \mathrm{~h}$ & -0.3963 & -0.0439 & 0.4166 & -0.1036 & 0.8064 & 1 & & \\
\hline & $14 \mathrm{~h}$ & 0.4607 & 0.2357 & -0.5252 & 0.2453 & -0.7994 & -0.7109 & 1 & \\
\hline $\mathrm{Gm}$ & $\left(\mathrm{g} \mathrm{g}^{-1}\right)$ & 0.0820 & 0.0002 & 0.1560 & -0.2156 & -0.4808 & -0.5088 & 0.3343 & 1 \\
\hline
\end{tabular}

$\mathrm{S}=$ real speed of displacement $\left(\mathrm{m} \mathrm{s}^{-1}\right) ; \mathrm{EFC}=$ effective field capacity $\left(\mathrm{ha} \mathrm{h}^{-1}\right) ; \mathrm{M}=$ average number of days to seedling emergence (days); IS = initial stand of culture ( $\mathrm{m}^{-2}$ plants); $\mathrm{COV}=$ soil cover percentage $(\%) ; \mathrm{T}=$ temperature of the soil; $\mathrm{Gm}=$ gravimetric moisture of the soil on a dry basis on 01-19-2012, at $0-0.10 \mathrm{~m}$ depth; the $\mathrm{R}$ values spelled in italics indicate the combination of variables also analyzed by linear regression (Table 5 ).

Table 5 - Regression analysis between variables in the implementation of the rice crop in three tillage systems, in the agricultural year 2011/2012, in Vale do Ribeira (Registro - SP). Average of $12^{(1)}$ or $6^{(2)}$ replicates.

\begin{tabular}{|c|c|c|c|c|c|}
\hline Variables (IxD) & Units & Equation & $\mathrm{R}^{2}$ & $P$ & CV $(\%)$ \\
\hline $\mathrm{S} \times \mathrm{EFC}^{(1)}$ & $\mathrm{m} \mathrm{s}^{-1} \times \mathrm{ha} \mathrm{h}^{-1}$ & $y=0.4905 x-0.1269$ & $0.5629^{* *}$ & 0.0001 & 4.46 \\
\hline $\operatorname{COV}^{(1)} \times E F C$ & $\% \times$ ha h$^{-1}$ & $y=-0.002 x+2.5328$ & $0.2000^{* *}$ & 0.0062 & 68.98 \\
\hline $\operatorname{COV} \times I^{(1)}$ & $\% \times$ plants $\mathrm{m}^{-2}$ & $y=-0.3044 x+160.6740$ & $0.1376^{*}$ & 0.0259 & 19.53 \\
\hline $\operatorname{COV} \times \operatorname{Tgh}_{92}^{(2)}$ & $\% \times \circ C$ & $y=3.10^{-05} x^{2}+0.0062 x+25.266$ & $0.8561^{* *}$ & 0.0001 & 0.87 \\
\hline $\operatorname{COV} \times \mathrm{T}_{14 \mathrm{~h}^{(2)}}$ & $\% \times \circ C$ & $y=-0.0005 x^{2}+0.0276 x+31.191$ & $0.7366^{* *}$ & 0.0001 & 1.95 \\
\hline $\operatorname{COV} \times \mathrm{Gm}^{(2)}$ & $\% \times g^{-1}$ & $y=-0.0006 x+0.2304$ & $0.2312^{*}$ & 0.0434 & 10.77 \\
\hline $\operatorname{COV} \times \mathrm{M}^{(1)}$ & $\% \times$ days & $y=0.0063 x+18.2818$ & $0.1921^{* *}$ & 0.0075 & 5.66 \\
\hline $\mathrm{T}_{9 h} \times \mathrm{T}_{14 \mathrm{~h}^{(2)}}$ & $\cdot \mathrm{C} x \cdot \mathrm{C}$ & $y=-1.8854 x+79.2384$ & $0.5054^{* *}$ & 0.0009 & 2.28 \\
\hline $\mathrm{T}_{9 h} \times \mathrm{Gm}^{(2)}$ & $\circ \mathrm{xg} \mathrm{g}^{-1}$ & $y=-0.0361 x+1.1428$ & $0.2589^{*}$ & 0.0310 & 10.57 \\
\hline $\mathrm{T}_{9 h} \times \mathrm{M}^{(2)}$ & $\% \times$ days & $y=0.5381 x-5.2455$ & $0.1736^{\mathrm{NS}}$ & 0.0855 & 5.16 \\
\hline $\mathrm{T}_{14 \mathrm{~h}} \times \mathrm{M}^{(2)}$ & $\% x$ days & $y=-0.2558 x+16.4551$ & $0.2758^{\star}$ & 0.0252 & 4.83 \\
\hline
\end{tabular}

$\mathrm{S}=$ real speed of displacement; $\mathrm{EFC}=$ effective field capacity; $\mathrm{M}=$ average number of days to seedling emergence; IS = initial stand of culture; $\mathrm{COV}=$ percentage of soil cover; $\mathrm{T}=$ temperature of the soil; $\mathrm{Gm}=$ gravimetric soil moisture in the depth of $0-0.10 \mathrm{~m} ;{ }^{\mathrm{NS}}=$ non-significant; ${ }^{*}=$ significant at $5 \%$ probability; ${ }^{* *}=$ significant at $1 \%$ probability. 


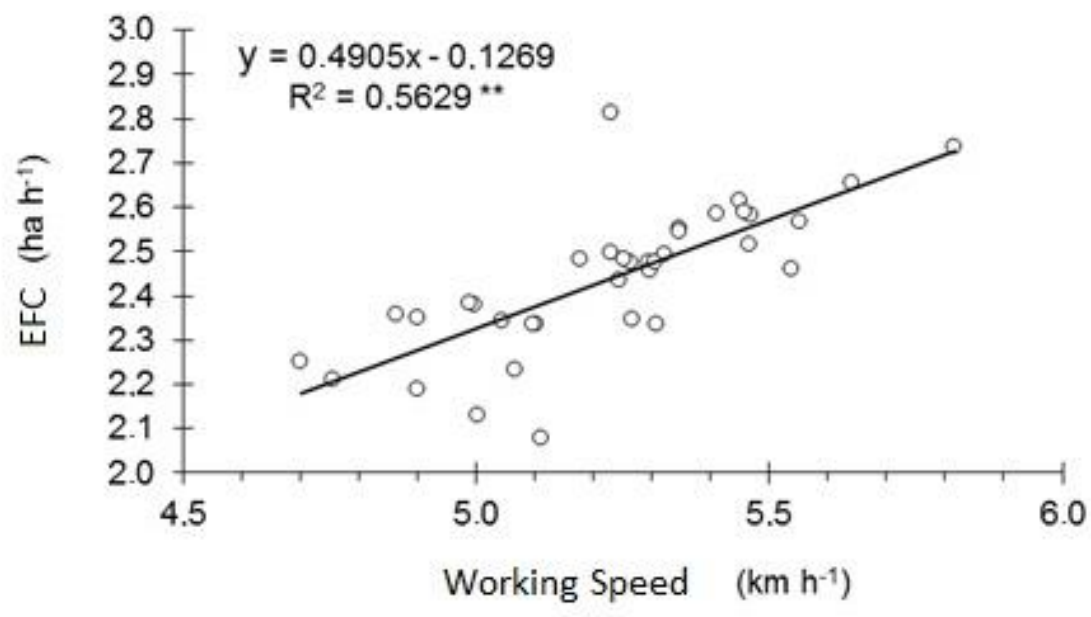

Figure 1 - Regression between the working speed and the effective field capacity after the implementation of the rice crop in three tillage systems, in the agricultural year 2011/2012, in Vale do Ribeira (Registro - SP).

The lower mobilization of the soil in NT, associated with greater surface vegetation cover, reduces the heating and cooling rate of the soil, which justifies the higher temperature in the morning hours (slow cooling) and the lower temperature in the afternoon (slower heating), as shown in Figure 2.

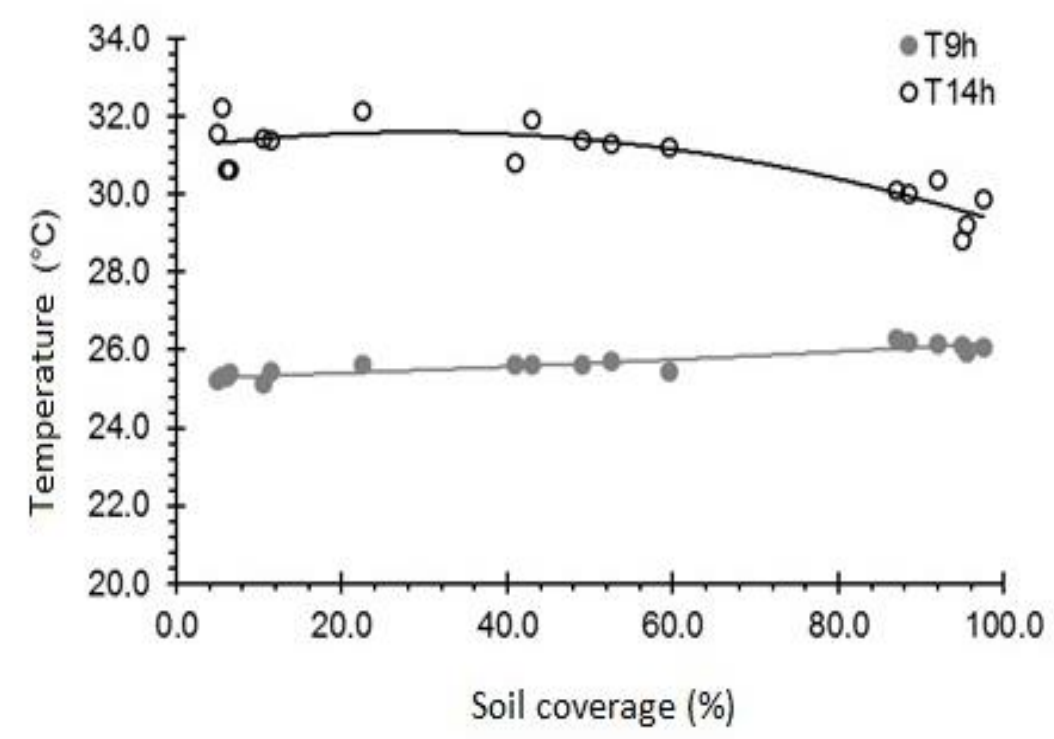

Figure 2 - Regression between the percentage of soil coverage and soil temperature at $9 \mathrm{~h}$ and $14 \mathrm{~h}$ after the implementation of the rice crop in three tillage systems, in the agricultural year 2011/2012, in Vale do Ribeira (Registro - SP).

The different amounts of vegetation cover according to the management system interfere in the dynamics of heating and cooling of the soil, thus, the soil temperature difference between $9 \mathrm{~h}$ and $14 \mathrm{~h}$ (thermal amplitude) is reduced with reduced tillage (Figure 3).

The fact that the systems have different amounts of coverage and interfere with the dynamics of heating and cooling of the soil can be seen in Figure 3, the difference between the temperatures at $9 \mathrm{~h}$ and $14 \mathrm{~h}$ (thermal amplitude) is reduced with the reduction of tillage. It is observed that the thermal range in the tillage system is reduced to half (around $3.0^{\circ} \mathrm{C}$ ) of that observed for the conventional system (around $6.0^{\circ} \mathrm{C}$ ), indicating greater thermal stability of the farming system, favoring the soil dynamics, essentially from the biological point of view (Silva et al., 2006). 


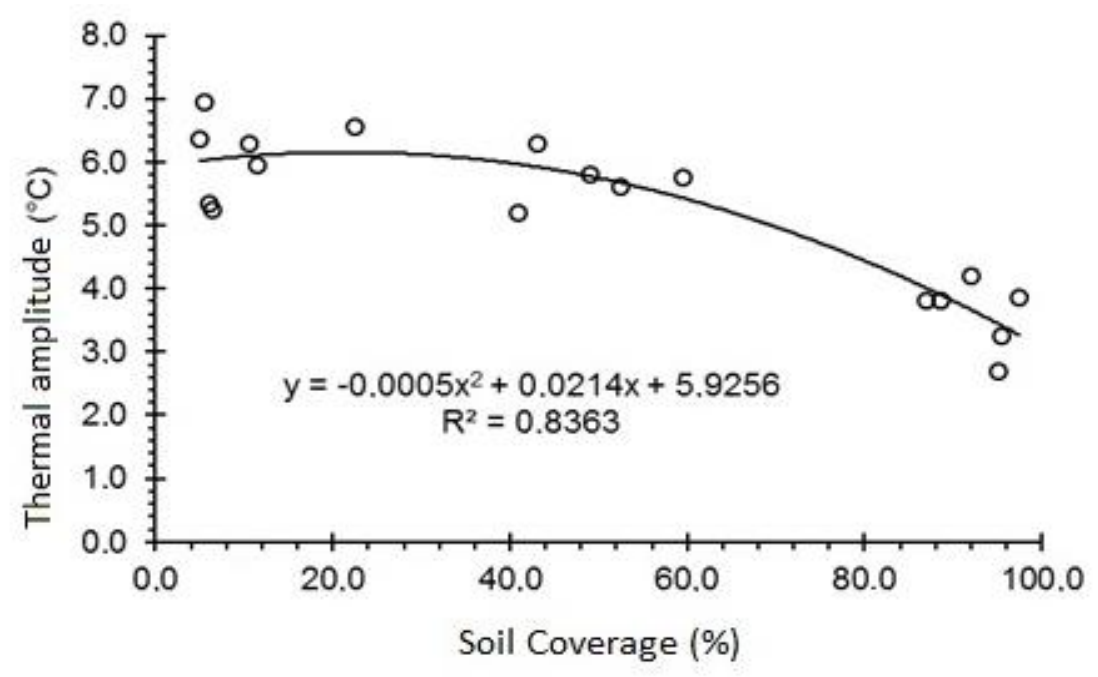

Figure 3 - Regression between the percentage of soil coverage and thermal amplitude after the implementation of the rice crop in three tillage systems, in the agricultural year 2011/2012, in Vale do Ribeira (Registro - SP).

\section{Conclusions}

Based on these results, one can conclude that: 1. the largest surface coverage in NT reduce the soil temperature and thermal amplitude in the hottest hour of the day (14h); 2 . the average number of days to seedling emergence of rice was higher in no-till, influenced by greater surface coverage and lower soil temperature in the hottest period of the day; 3 . the initial stand of the rice crop was similar in the three tillage systems.

\section{Acknowledgements}

To PROPe - Pro-Rectory of Research of UNESP for the research assistance (First Projects Notice 2011).

\section{References}

Akune, VSC (2015) Cultivo de milho verde em sucessão ao arroz no Vale do Ribeira, SP: subsídios para adoção de zonas de manejo. Unesp (Dissertação de mestrado em Agronomia).

Alam K, Islam M, Salahin N, Hasanuzzaman M (2014) Effect of tillage practices on soil properties and crop productivity in wheat-mungbean-rice cropping system under subtropical climatic conditions. The Scientific World Journal 2014:1-15. doi: 10.1155/2014/437283

Arf O, Bastos J, Silva M, Sá M, Rodrigues RAF, Buzetti $S$ (2005) Manejo do solo e época de aplicação de nitrogênio na produção de arroz de terras altas. Acta Scientiarum. Agronomy 27(2):215-223.

ASAE - American Society of Agricultural Engineers (2005). Terminology and definitions for Soil tillage and soil-tool relationships. (ASAE EP291.3) ASAE Standards 52:130-134. Disponível em: <http://www3.abe.iastate.edu/ast330/Lectures/ASAE EP291.pdf. > (Acesso em 29 jun 2015).
ASAE - American Society of Agricultural Engineers (1999). Agricultural machinery management data. (ASAE D497.2). ASAE Standards 332-339.

Bertolini EV, Gamero CA, Cunha AS, Piffer CR (2012) Demanda energética da semeadura do milho em diferentes manejos do solo e espaçamentos entre linhas. Nucleus 9(2):185-194. doi: 10.3738/1982.2278.738

Cavalcante EG, Alves MC, Souza ZM, Pereira G (2011) Variabilidade espacial de atributos físicos do solo sob diferentes usos e manejos. Revista Brasileira de Engenharia Agrícola e Ambiental 15(3): 237-243.

Cortez JW, Furlani CEA, Silva RP, Carvalho Filho A (2007) Parâmetros de avaliação no solo, na máquina e na planta sob plantio direto. Revista Plantio Direto 98(2):22-26.

Chioderoli CA, Furlani CEA, Silva RP, Gitti DC, Kaneko FH, Roman RAA (2010) Desempenho de semeadora-adubadora em função do preparo de solo e espaçamento da cultura do milho. Pesquisa Agropecuária Tropical 40(4):462-467.

Embrapa (1997) Manual de métodos de análise de solo. 2.ed. Rio de Janeiro, Centro Nacional de Pesquisa de Solos. 212p.

Embrapa (2011) Cultivo do Milho. Sistemas de Produção/EMBRAPA. Disponível em: $<$ http://sistemasdeproducao.cnptia.embrapa.br/Font esHTML/Milho/CultivodoMilho_7ed/index.htm> (Acesso em: 26 jun. 2015).

Fonseca, AE, Arf, O, Júnior, VO, Buzetti, S, Rodrigues, RAF (2012). Preparo do solo e doses de nitrogênio em cobertura em arroz de terras altas. Pesquisa Agropecuária Tropical (Agricultural Research in the Tropics), 42(3). 
Furlani, CE, Lopes, A, Silva, RD. (2005). Avaliação de semeadora-adubadora de precisão trabalhando em três sistemas de preparo do solo. Revista Brasileira de Engenharia Agrícola, 25(2), 458-464.

Kamimura, KM, Alves, MC, Arf, O, Binotti, F F D S (2009). Propriedades físicas de um Latossolo Vermelho sob cultivo de arroz de terras altas em diferentes manejos do solo e água. Bragantia, 723-731.

Kaneko, FH, Arf, O, Gitti, DC, Arf, MV, Ferreira, JP, Buzetti, S (2010). Mecanismos de abertura de sulcos, inoculação e adubação nitrogenada em feijoeiro em sistema plantio direto. Bragantia, v.69, p.125-133.

Kraemer AF, Marchesan E, Avila LA, Machado SLO, Grohs M, Massoni PFS, Sartori GMS (2009) Persistência dos herbicidas imazethapyr e imazapic em solo de várzea sob diferentes sistemas de manejo. Planta Daninha 27(3):581-588.

Laflen JM, Amemiya A, Hinitz EA (1981) Meassuring crop residue cover. Soil Water Conservation, Ankeny, 36(6):341-343.

Mello EL, Bertol I, Zaparolli ALV (2003) Perda de solo e água em diferentes sistemas de manejo de um Nitossolo haplico submetido à chuva simulada. Revista Brasileira de Ciência do Solo 27(5):901-909.

Maguire JD (1962) Speed of germination-aid in selection and evaluation for seedling emergence and vigor. Crop Science 2(2):176-177.

Martorano LG, Bergamaschi H, Dalmago GA, Faria RT, Mielniczuk J, Comiran F (2009) Indicadores da condição hídrica do solo com soja em plantio direto e preparo convencional. Revista Brasileira de Engenharia Agrícola e Ambiental 13(4):397-405.

Nascente, AS, Kluthcouski, J, Rabelo, RR, Oliveira, PD, Cobucci, T, Crusciol, CAC (2011). Desenvolvimento e produtividade de cultivares de arroz de terras altas em função do manejo do solo. Pesquisa Agropecuária Tropical, 186-192.

Oi WM (2008) Manejo do solo e da adubação nitrogenada em arroz de terras altas irrigado por aspersão. UNESP (Dissertação mestrado em Agronomia).

Pimentel-Gomes, F., Garcia, C. H. (2002). Estatística aplicada a experimentos agronômicos e florestais: exposição com exemplos e orientações para uso de aplicativos. Piracicaba: Fealq. 309p.

Raij B van, Cantarella H, Quaggio JA (1997) (Eds.) Recomendações de adubação e calagem para o Estado de São Paulo. IAC. 285p.

Reis, M. A. M., Chioderoli, C. A., Macedo, D. X. S., Albiero, D., Almeida, L. (2014) Milho em função do preparo do solo e das cargas verticais no depósito de fertilizantes. In: XLIII Congresso Brasileiro de Engenharia Agrícola. Campo Grande- MS: CONBEA, v.43.
Reis EF, Moura JR, Delmond JG, Cunha JPAR (2007) Características operacionais de uma semeadora-adubadora de plantio direto na cultura da soja (Glycine Max (L.) Merril). Revista Ciências Técnicas Agropecuárias 16(3):70-75.

Rodrigues JGL, Fernandes JC, Nascimento FM, Gamero CA, Bicudo SJ (2011) Caracterização física do solo e desempenho operacional de máquinas agrícolas na implantação da cultura do sorgo forrageiro. Semina: Ciências Agrárias 32(4):18131824.

Ross JLS (2002) A morfogênese da Bacia do Ribeira do lguape e os sistemas ambientais. Revista GEOUSP Espaço e Tempo (12): 21-46.

Silva, MAS, Albuquerque, LMJA, Mielniczuk, CBJ (2005). Atributos físicos do solo relacionados ao armazenamento de água em um Argissolo Vermelho sob diferentes sistemas de preparo. Ciência Rural, 35(3):544-552.

Silva, JG, Kluthcouski, J, Stone, LF, Aidar, H, Oliveira, IP, Ferreira, E (1998). Desempenho de semeadoras-adubadoras no estabelecimento da cultura do arroz de sequeiro. Revista Pesquisa Agropecuária Brasileira, 33(1), 63-70.

Silva JG (2004) Plantio direto do arroz influenciado por tipos de sulcadores e compactadores de sulcos da semeadora adubadora. Embrapa Arroz e Feijão. 4p.

Silva RP, Cora JE, Filho AC, Furlani CEA, Lopes A (2008) Efeito da profundidade de semeadura e de rodas compactadoras submetidas a cargas verticais na temperatura e no teor de água do solo durante a germinação de sementes de milho. Ciência e Agrotecnologia 32: 929-937.

Silva VR, Reichert JM, Reinert DJ (2006) Variação na temperatura do solo em três sistemas de manejo na cultura do feijão. Revista Brasileira de Ciência do Solo 30(3):391-399.

Torres JLR, Fabian AJ, Pereira MG (2011) Alterações dos atributos físicos de um Latossolo Vermelho submetido a diferentes sistemas de manejo. Ciência e Agrotecnologia 35(3):437-445.

Vale WG, Garcia RF, Thiebaut JTL, Amim RT, Tourino MCC (2008) Desempenho e dimensionamento amostral para avaliação de uma semeadora-adubadora em plantio direto e convencional. Acta Scientyarum. Agronomy 30(4):441-448. 